\title{
Differential regulation of transcription factor gene expression and phenotypic markers in developing sympathetic neurons
}

\author{
Andrew K. Groves ${ }^{1}$, Kathleen M. George ${ }^{3}$, Jean-Phillipe Tissier-Seta ${ }^{4}$, James Douglas Engel ${ }^{3}$, \\ Jean-François Brunet ${ }^{4}$ and David J. Anderson ${ }^{1,2, *}$ \\ 1Division of Biology 216-76 and ${ }^{2}$ Howard Hughes Medical Institute, California Institute of Technology, Pasadena, CA 91125, USA \\ ${ }^{3}$ Department of Biochemistry, Northwestern University, Evanston, IL, USA \\ 4Laboratoire de Génétique et Physiologie du Developpment, CNRS-Université Aix-Marseille II, Case 907, F-13288 Marseille \\ Cedex 9, France
}

${ }^{*}$ Author for correspondence

\section{SUMMARY}

We have examined the regulation of transcription factor gene expression and phenotypic markers in developing chick sympathetic neurons. Sympathetic progenitor cells first express the bHLH transcriptional regulator Cash-1 (a chicken achaete-scute homologue), followed by coordinate expression of Phox2, a paired homeodomain protein, and GATA-2, a zinc finger protein. SCG10, a pan-neuronal membrane protein, is first detected one stage later, followed by the catecholaminergic neurotransmitter enzyme tyrosine hydroxylase (TH). We have used these markers to ask two questions: (1) is their expression dependent upon inductive signals derived from the notochord or floor plate?; (2) does their sequential expression reflect a single linear pathway or multiple parallel pathways? Notochord ablation experiments indicate that the floor plate is essential for induction of GATA-2, Phox 2 and TH, but not for that of Cash-1 and SCG10. Taken together these data suggest that the development of sympathetic neurons involves multiple transcriptional regulatory cascades: one, dependent upon notochord or floor plate-derived signals and involving Phox2 and GATA-2, is assigned to the expression of the neurotransmitter phenotype; the other, independent of such signals and involving Cash-1, is assigned to the expression of pan-neuronal properties. The parallel specification of different components of the terminal neuronal phenotype is likely to be a general feature of neuronal development.

Key words: transcription factor gene, gene expression, phenotypic marker, neuron, sympathetic neuron, GATA-2, Phox2, TH, Cash-1, SCG10

\section{INTRODUCTION}

A central problem in developmental neurobiology is to understand the mechanisms that control the generation of different neuronal cell types. Genetic and molecular analyses in $C$. elegans and Drosophila have revealed that the determination of neuronal identity is a progressive process that involves cascades of transcriptional regulatory factors (Ghysen and Dambly-Chaudiere, 1992; Sternberg et al., 1992). These transcription factors control distinct operations that act within the lineages that generate particular classes of neurons (Ghysen and Dambly-Chaudiere, 1989). The extent to which these operations are carried out in a strictly linear fashion, or alternatively in parallel, is not yet clear. Nevertheless, this powerful method of analysis has provided a formal logical description of some of the steps involved in neurogenesis, as well as an identification of some of the key genes that regulate these steps (Ghysen et al., 1993).

Studies of cell type determination in other lineages, such as muscle, have emphasized the idea that most or all of the lineage-specific genes expressed by differentiated cells are coordinately activated by master transcriptional regulators, such as members of the MyoD family, which thereby function as unitary determinants of cell type (Weintraub et al., 1991). The enormous diversity of neuronal cell types, however, raises the question of how such a simple mechanism could generate such diversity without requiring a very large number of different master regulatory genes. More likely, neuronal phenotypes are specified by combinations of transcriptional regulators. For example, as some aspects of the neuronal phenotype (e.g., axons, dendrites, synaptic vesicles) are common to most or all neurons, these characteristics could be specified by a small number of broadly expressed neuron-specific regulatory genes. Those components of the phenotype that are specific to subclasses of neurons, such as neurotransmitter-synthesizing enzymes, could be controlled by a more diverse set of regulatory molecules with restricted distributions within the nervous system. Such a combinatorial mechanism raises the issue of how the different regulatory molecules in a neuronal precursor are themselves controlled during development.

To begin to address this issue, we have focused on one of the most extensively characterized types of vertebrate neuron: 
the peripheral sympathetic neuron. These neurons develop from neural crest cells (LeDouarin, 1982) which emerge from the dorsal neural tube, migrate past the notochord, and condense to form ganglion primordia adjacent to the dorsal aorta (for review, see Anderson, 1993). As they differentiate, these cells express pan-neuronal genes such as neurofilament (Cochard and Paulin, 1984) and SCG10 (Anderson and Axel, 1985; Stein et al., 1988a), as well as lineage-specific genes involved in neurotransmitter biosynthesis such as tyrosine hydroxylase (TH) (Cochard et al., 1979) and dopamine $\beta$ hydroxylase (DBH) (Mercer et al., 1991). While norepinephrine is the predominant classical neurotransmitter synthesized by sympathetic neurons, small subclasses of these neurons can synthesize acetylcholine and various neuropeptides in response to target-derived inductive factors (for reviews, see Landis, 1992; Patterson, 1990).

A number of specifically expressed transcriptional regulators have recently been identified in sympathetic precursors. One such factor, Mash-1, is a mammalian homologue of the Drosophila proneural genes achaete-scute. (Johnson et al., 1990; Lo et al., 1991). Mash-1 function is essential for the development of autonomic (as well as olfactory) neurons as demonstrated by targeted mutagenesis experiments in mice (Guillemot et al., 1993; Lo et al., 1994). Two other transcription factors specifically expressed in autonomic precursors are Phox2 (a paired homeodomain protein (Valarché et al., 1993)) and GATA-2 (a Zn-finger transcription factor (Yamamoto et al., 1990)). Although Phox 2 was originally isolated as a regulator of NCAM gene expression, its expression pattern in vivo is most closely correlated with expression of a noradrenergic neurotransmitter phenotype (Valarché et al., 1993). The function of these two transcription factors in sympathetic development has not yet been determined.

In chick embryos, rotation of the neural tube and concomitant removal of the notochord prevents the expression of catecholamine histofluorescence in condensing sympathetic neuroblasts (Stern et al., 1991). This indicates that at least some aspects of sympathetic differentiation are dependent upon notochord/ventral neural tube (VNT)-derived signals. Here we have asked whether the induction of specific transcriptional regulators is also affected by such a manipulation. We find that induction of Phox 2 and GATA-2 is blocked by notochord/floorplate ablation, as is that of TH (another marker of the catecholaminergic phenotype). Surprisingly, however, induction of Cash-1 is unaffected in many cells. SCG10 expression is also detected in operated embryos, although the number of positive cells is reduced. These results suggest (1) that different transcriptional regulators in sympathetic progenitors are differentially regulated by cell-extrinsic signals; (2) that induction of the pan-neuronal and neurotransmitter-synthesizing components of the sympathetic neuron phenotype can be experimentally uncoupled; (3) that Phox 2 and GATA2 may be involved in the specification of sympathetic neurotransmitter phenotype, while Cash-1 is involved in the specification of pan-neuronal components of the phenotype. Taken together, these conclusions support the general idea that a particular neuronal phenotype may be determined by several parallel regulatory cascades operating in progenitor cells, which converge to activate a coordinated ensemble of specialized cellular properties.

\section{MATERIALS AND METHODS}

\section{Embryos and microsurgery}

Chicken eggs were obtained from local suppliers and maintained at $38^{\circ} \mathrm{C}$ in an humidified incubator until the embryos reached Hamburger and Hamilton stages 9-11 (Hamburger and Hamilton, 1992). Surgery was performed according to the methods described by Stern (Stern, 1993; Stern and Keynes, 1987). Briefly, the embryo was lowered by the removal of $0.5 \mathrm{ml}$ of thin albumen from the egg, and a square hole was cut in the egg shell. The yolk was floated with calcium- and magnesium-free Tyrode's saline (CMF), and the embryo visualised by injection of a solution of Indian ink beneath the blastoderm. Operations were performed under a standing drop of $0.15 \%$ trypsin in CMF using electrolytically sharpened tungsten needles, 30G hypodermic needles and microscalpels (Moria, France).

The vitelline membrane was deflected from the unsegmented region of the embryo and incisions were made to separate the unsegmented mesoderm from the neural plate. The notochord was carefully freed from both the neural plate and the underlying endoderm, and then removed. Particular care was taken to extirpate the most caudal regions of the notochord; it was found that this increased the likelihood of operated embryos containing regions of spinal cord lacking a floor plate.

Following notochord ablation, the embryo and yolk were lowered back into the egg by the removal of more thin albumen, the egg was sealed with electrical tape and returned to the incubator for a further 2-4 days. The results in the present study are based on the analysis of 67 operated embryos.

\section{Histology and immunocytochemistry}

Normal or operated embryos were fixed overnight in $4 \%$ paraformaldehyde, washed in phosphate-buffered saline (PBS) and equilibrated in $30 \%$ sucrose overnight at $4{ }^{\circ} \mathrm{C}$. Embryos were placed in Tissue Tek embedding material for 30 minutes, and then frozen rapidly on dry ice. Serial sections between 15 and $25 \mu \mathrm{m}$ were cut on a Bright cryostat. Normal embryos between stages 16 and 20 were equilibrated in $15 \%$ sucrose after fixation, followed by infiltration with $15 \%$ sucrose $/ 7.5 \%$ gelatin at $37^{\circ} \mathrm{C}$ for 2 hours before being frozen and sectioned.

The following antibodies were used in the present study. The HNK1 mouse IgM monoclonal was used as a marker for neural crest cells (Tucker et al., 1984). The FP1 mouse IgG monoclonal, used as a marker for floor plate cells (Yamada et al., 1991) was a gift of Dr Tom Jessell. The PCTH-7 mouse IgG monoclonal to the chicken tyrosine hydroxylase enzyme was a gift of Dr Hiroshi Hatanaka.

Sections were briefly fixed in $4 \%$ paraformaldehyde, washed several times in PBS and incubated in PBS containing 5\% goat serum, $0.4 \%$ Triton $\mathrm{X}-100$ and $0.25 \%$ BSA for 3 hours at room temperature. Primary antibodies were diluted in the same buffer and applied to the slides overnight at $4^{\circ} \mathrm{C}$. The slides were washed several times in PBS and endogenous peroxidase activity was quenched by incubating with $0.3 \% \mathrm{H}_{2} \mathrm{O}_{2}$ in methanol for 30 minutes at room temperature. The slides were washed again in PBS, and incubated with appropriate goat anti-mouse secondary antibodies conjugated to horseradish peroxidase (HRP) for 1 hour. The slides were then washed and processed for the HRP reaction using diaminobenzidine as a substrate.

\section{In situ hybridisation}

Serial sections from normal and operated chick embryos were processed for non-radioactive in situ hybridisation using digoxigeninlabeled complementary RNA (cRNA) probes by a modification (Birren et al., 1993) of the protocol of Harland (Harland, 1991). Normal chick embryos were processed for whole-mount in situ hybridisation using a modification of the protocol of Wilkinson (Wilkinson, 1992). Detailed protocols are available upon request. The following cRNA probes were used in this study: CASH-1 (the chicken 
homologue of MASH-1; (Jasoni et al., 1994), a chicken homologue of GATA-2 (Yamamoto et al., 1990), a chicken homologue of Phox2 ((Valarché et al., 1993); C. Goridis and J.-P. Brumet, personal communication), and a chicken homologue of SCG10 (Anderson and Axel, 1985; Stein et al., 1988a,b); P. Jeffrey, personal communication).

\section{RESULTS}

\section{Successive expression of molecular markers defines a sequence of stages in sympathetic neurogenesis}

We have examined the expression pattern of three specifically expressed transcription factor-encoding genes (Cash-1, Phox 2 and GATA-2) and two differentiation genes (SCG10 and TH) in developing chick embryos by non-radioactive in situ hybridization and immunocytochemistry. We used SCG10 as a marker of the neuronal phenotype, and TH as a marker of the catecholamine-synthesizing neurotransmitter phenotype. SCG10 encodes a membrane-associated phosphoprotein that is expressed by all CNS and PNS neurons at the onset of differentiation (Stein et al., 1988a,b); in this respect, its expression pattern is similar to that of other neuron-specific markers such as neurofilament $\left(68 \times 10^{3} M_{\mathrm{r}}\right.$ subunit) (Cochard and Paulin, 1984). In situ hybridization for SCG10 mRNA identifies the position of sympathetic neuronal cell bodies without interference from nerve fibers labeling, which confuses the interpretation of anti-neurofilament antibody staining (Guillemot et al., 1993).

Neural crest cells condense to form sympathetic ganglion primordia around the dorsal aorta at Hamburger and Hamilton stage 16 (Hamburger and Hamilton, 1992) (stage 16), when they can be identified by staining with monoclonal antibody HNK-1. At this stage, none of the other markers is expressed (not shown). Whole-mount in situ hybridization analysis revealed that the first of the markers to be expressed in the ganglion primordia is Cash-1, which appears at stage 17 (Fig. 1). In adjacent serial sections, the domains of Cash- 1 and HNK-1 expression around the dorsal aorta appeared to be similar (Fig. 2B,C). Both GATA-2 and Phox 2 mRNAs were first detectable at stage 18 (Fig. 1, arrowheads). By stage 19, the first traces of SCG10 mRNA expression were detectable in the sympathetic primordia (Fig. 1). TH expression is not detectable in trunk sympathetic ganglia until stage 24 . At this stage, all five markers transiently overlap when examined in adjacent serial sections (Fig. 2). Subsequently, expression of Cash-1 is extinguished (as shown previously in rat (Lo et al., 1991)), while that of the other markers persists. Collectively, therefore, these markers define six successive ontogenic stages of sympathetic development (Fig. 2, lower).

It has been clearly demonstrated that TH and SCG10 are expressed by all primary sympathetic neurons (Anderson and Axel, 1985; Cochard et al., 1979; Stein et al., 1988a), and that Mash-1 (the mammalian homologue of Cash-1) is expressed in and required for the differentiation of all such neurons (Guillemot et al., 1993; Lo et al., 1991). To determine whether Phox 2 and GATA-2 are likely to be expressed by all sympathetic neuroblasts, we compared the number of cells expressing these markers to the number of $\mathrm{SCG}_{10}{ }^{+}$and $\mathrm{TH}^{+}$cells in adjacent sections. The results indicate that the population of positive cells for each of these markers is statistically indistinguishable from the others in serial sections (Table 1). These data support the idea that these markers are sequentially expressed by a single cell population and not by distinct but intermingled subpopulations.

\section{Differential expression of GATA-2, Cash-1 and Phox2 in other autonomic precursor populations}

Indirect evidence suggests that precursors of sympathetic neurons are lineally related to precursors of some other autonomic neurons, such as a subset of enteric neurons (Anderson, 1993a; Baetge and Gershon, 1989; Baetge et al., 1990; Carnahan et al., 1991). As these enteric neuronal precursors occupy a different local environment to sympathetic precursors, we sought to determine whether they would also express a different combination of molecular markers from those expressed by sympathetic precursors. At stage 25, differentiating enteric neurons in the stomach wall, revealed by SCG10 and HNK-1 expression (Fig. 3A,E), express both Cash1 and Phox2 but not GATA-2 (Fig. 3B-D). By contrast, cells in the ganglion of Remak (which consists at least in part of parasympathetic neurons and also some $\mathrm{TH}^{+}$neurons; (Cantino et al., 1982; Le Douarin et al., 1978; Teillet, 1978)), appeared to express all three transcription factor-encoding genes (Fig. 3F-J). These data indicate that, at this stage of development, Cash-1 and Phox 2 are expressed by representatives of all three major autonomic sublineages (sympathetic, parasympathetic and enteric), whereas expression of GATA-2 appears to be restricted to sympathetic and at least one parasympathetic lineages.

\section{Notochord ablation does not perturb sympathetic development in embryos that contain a floor plate}

Previous studies have indicated that signals from the ventral neural tube and/or notochord are required for catecholaminergic differentiation of sympathetic neurons (Cohen, 1972; Howard and Bronner-Fraser, 1986; Kalcheim and Le Douarin, 1986; Norr, 1973; Sieber-Blum and Cohen, 1980; Stern et al., 1991; Teillet et al., 1978; Teillet and Le Douarin, 1983). We therefore wished to determine whether these structures are similarly required for any or all of the stages in sympathetic development defined by the markers described above.

The most caudal region of the notochord (typically of between 300 and $500 \mu \mathrm{m}$ length) was surgically ablated in 67 chick embryos between stages 9 and 11 . This is substantially earlier than the initiation of neural crest migration, which begins in the trunk at stage 16 (Newgreen and Erickson, 1986). Thus, neural crest cells in operated embryos are unlikely to have experienced an influence of the notochord prior to the time of its extirpation (although their neural tube-derived precursors (Bronner-Fraser and Fraser, 1988) may have been exposed to similar signals derived from Hensen's node). Operated embryos were serially sectioned and processed for detection of the different markers. In each series of sections, the antibody HNK-1 was also used to identify neural crest cells condensing near the dorsal aorta.

Although in most operated embryos notochord ablation prevented floor plate formation (see below), in some specimens (in which the notochord was not removed sufficiently caudally), floor plate induction recovered along the length of the embryo and the spinal cord was morphologically normal 


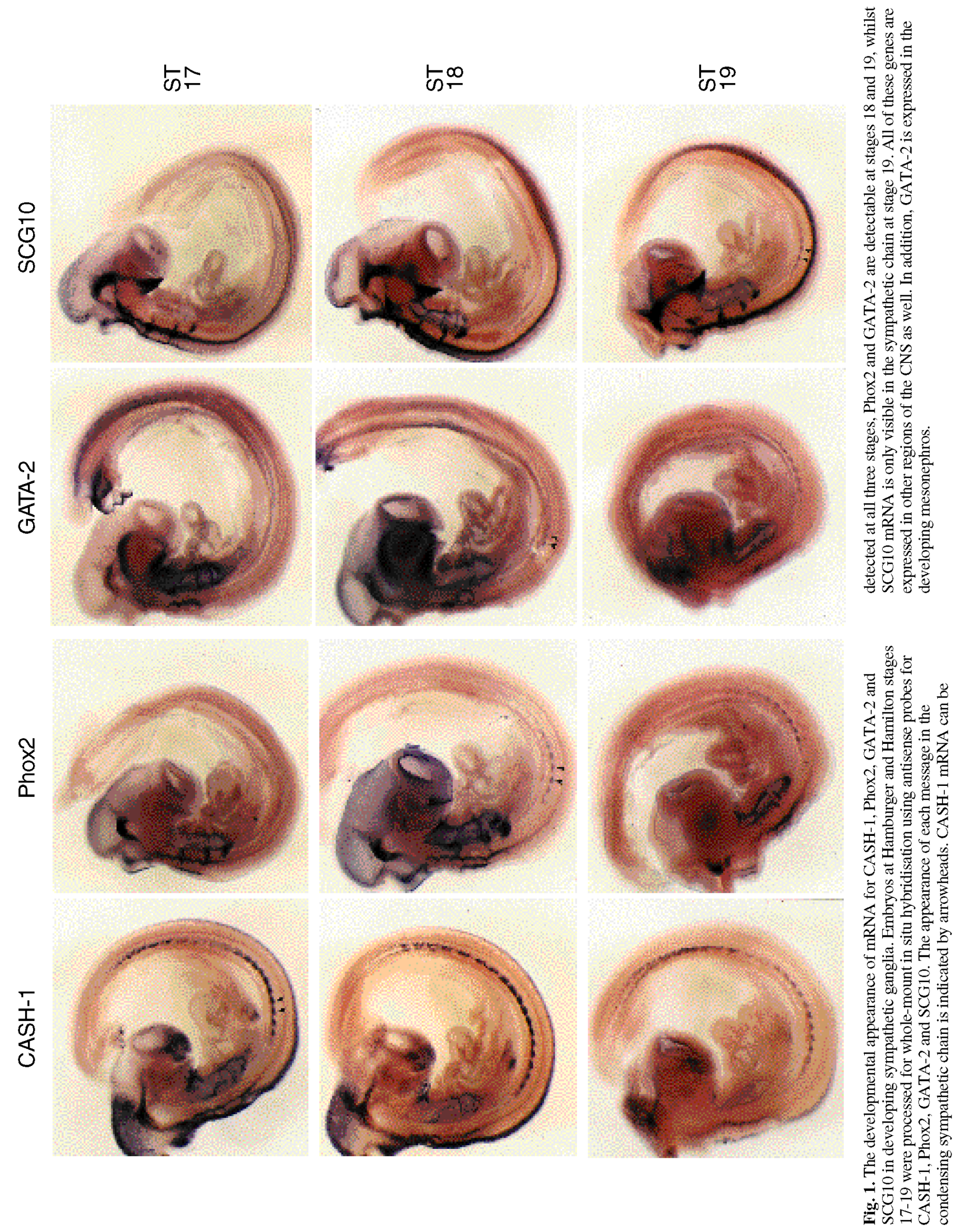




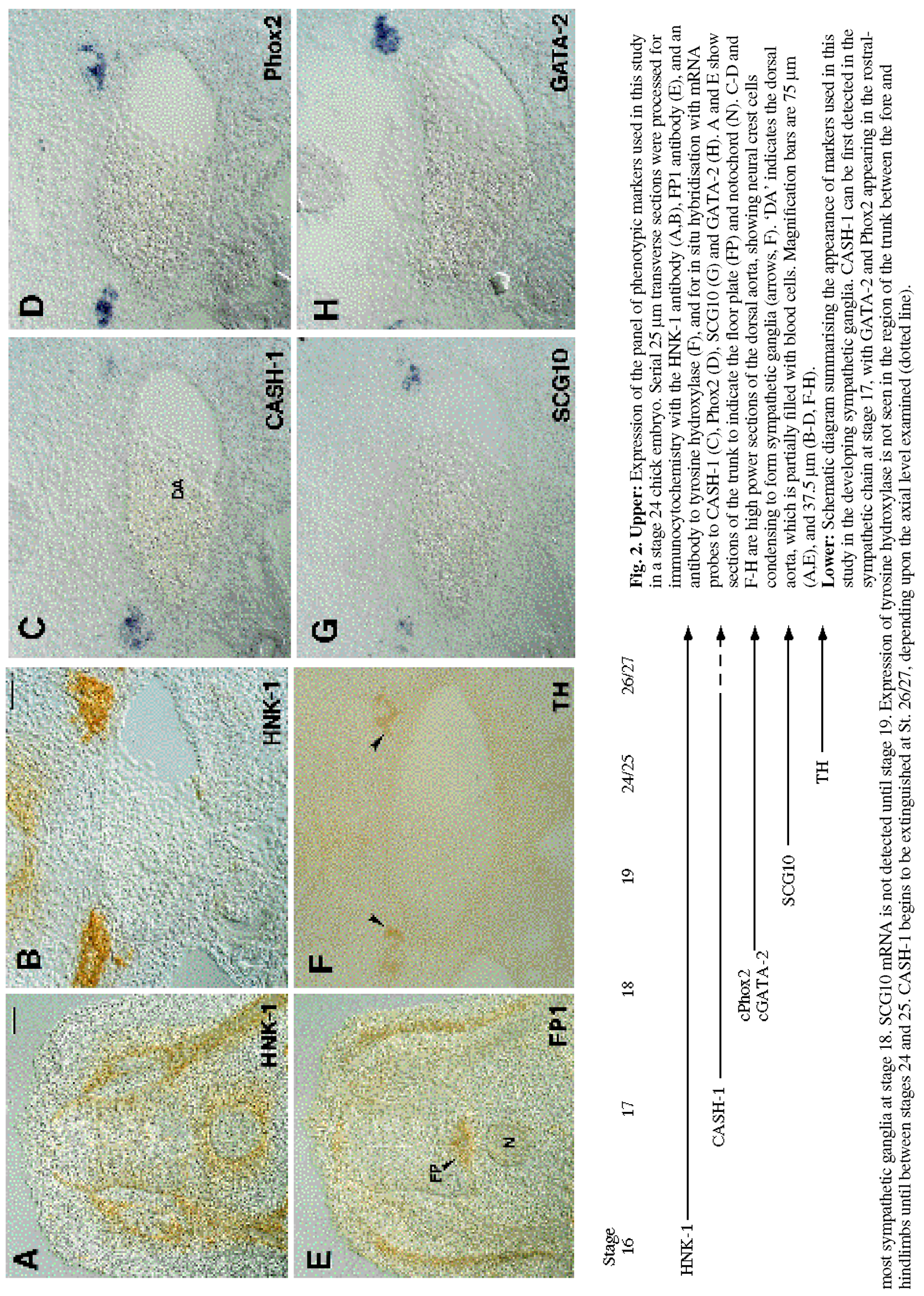


Table 1. Expression of lineage markers in sympathetic precursor cells

\begin{tabular}{lccc}
\hline TH & Phox2 & SCG10 & GATA-2 \\
\hline 169 & 193 & 152 & 139 \\
124 & 140 & 156 & 154 \\
122 & 102 & 117 & 101 \\
113 & 102 & 116 & 128 \\
72 & 78 & 84 & 55 \\
105 & 127 & n.d. & 83 \\
116 & 133 & 90 & n.d. \\
116 & 129 & 125 & 130 \\
48 & 126 & 142 & 99 \\
126 & 74 & 110 & 104 \\
86 & 114 & 99 & 116 \\
115 & 156 & 200 & 196 \\
& & & \\
$\mathbf{1 0 9 . 3} \pm \mathbf{2 9 . 0}$ & $\mathbf{1 2 2 . 8 \pm 3 1 . 4}$ & $\mathbf{1 2 6 . 5} \pm \mathbf{3 2 . 4}$ & $\mathbf{1 1 8 . 6} \mathbf{3 5 . 8}$
\end{tabular}

Similar numbers of sympathetic precursors express the lineage markers TH, SCG10, Phox 2 and GATA-2. The number of cells positive for each of the markers shown in the table was counted in adjacent serial sections in a stage 25 unoperated embryo. Cash-1 is being down-regulated in the sympathetic ganglia at this stage and was therefore not scored. Twelve sets of adjacent sections were scored. The means \pm s.e.m. are given in bold face at the bottom of the table. None of the four populations are significantly different from one another when compared using a Mann-Whitney test $(P<0.05$ in each case). n.d., not determined (section damaged during processing). These data support the conclusion that Phox 2 and GATA-2 are expressed by the same population of cells as expresses TH and SCG10.

(Fig. 4A,D) (see also (Artinger and Bronner-Fraser, 1993; van Straaten and Hekking, 1991; Yamada et al., 1991)) Examination of these embryos revealed no abnormalities in sympathetic neuronal differentiation at either stages $21-23$ or $25-27$ when assayed with the panel of markers described above. In the majority of cases, aggregates of HNK-1 cells could be seen between the dorsal aorta and neural tube (Fig. 4B) that expressed SCG10, TH and GATA-2 (Fig. 4C,E,F) and Phox2 (not shown) at stage 26. Furthermore, such HNK1-positive aggregates were also positive for Cash-1 in embryos examined between stages 21 and 23 (not shown). These data suggest that the notochord is not necessary for differentiation of neural crest cells into mature sympathetic neurons provided a floor plate is present, a conclusion consistent with earlier results (Stern et al., 1991). Our inability to examine individual operated embryos at multiple time points, however, leaves open the possibility that transient or partial notochord development occurred in these embryos and contributed to induction of the markers tested.

\section{The floor plate is essential for induction of a subset of sympathetic differentiation markers}

In other studies, it has been shown that removal of the notochord at sufficiently early developmental stages causes the formation of a neural tube in which a floor plate is lacking in at least some regions along its length (Artinger and BronnerFraser, 1993; Goulding et al., 1993; Hirano et al., 1991; Smith and Schoenwolf, 1989; van Straaten and Hekking, 1991; Yamada et al., 1991). We therefore used the floor-platespecific marker FP1 to identify in serial sections those regions of operated embryos in which both the notochord and floor plate were missing. Because the periods of maximal Cash-1 and $\mathrm{TH}$ expression do not overlap significantly, we chose to assess the effect of this manipulation on expression of these two markers in embryos of different ages. Therefore, the operated embryos were divided into two experimental groups. 27 embryos were analysed after developing to stages 21-23, in order to examine Cash-1 expression, whilst a second series of 40 embryos were analysed at stages 25 and 27 for expression of TH. In both groups, expression of Phox2, GATA-2 and SCG10 were also examined.

The results of these experiments are summarized in Table 2. The main observation was that, in embryos lacking a notochord and floor plate, expression of GATA-2, Phox 2 and TH was undetectable in most neural crest cells condensing near the dorsal aorta. In contrast, Cash-1 and SCG10 expression were readily detected in such cells, although their number was reduced relative to controls, more so in the case of SCG10. These observations suggest the existence of at least two separable regulatory pathways controlling the expression of different aspects of the sympathetic neuron phenotype, and are described in more detail below.

Table 2. Prevention of the formation of ventral neural tube structures affects certain aspects of sympathetic ganglion development

\begin{tabular}{|c|c|c|c|c|c|}
\hline \multirow[b]{2}{*}{ Marker } & \multicolumn{2}{|c|}{ Unoperated embryos } & \multicolumn{2}{|c|}{ Operated embryos } & \multirow[b]{2}{*}{$\begin{array}{l}\text { Fold reduction in } \\
\text { cell number in } \\
\text { operated embryos }\end{array}$} \\
\hline & $\begin{array}{c}\% \text { of Sections } \\
\text { containing cells } \\
\text { positive for marker }\end{array}$ & $\begin{array}{l}\text { Average number of } \\
\text { positive cells per } \\
\text { section }\end{array}$ & $\begin{array}{c}\% \text { of Sections } \\
\text { containing cells } \\
\text { positive for marker }\end{array}$ & $\begin{array}{l}\text { Average number of } \\
\text { positive cells per } \\
\text { section }\end{array}$ & \\
\hline CASH-1 & 100 & $82.1 \pm 31.3$ & 93.3 & $34.0 \pm 24.9$ & 2.4 \\
\hline SCG10 & 100 & $39.9 \pm 25.6$ & 38.6 & $7.3 \pm 12.9$ & 5.5 \\
\hline Phox2 & 100 & $47.3 \pm 22.1$ & 7.7 & $1.3 \pm 2.0$ & 36.4 \\
\hline GATA-2 & 100 & $37.2 \pm 21.2$ & 3.6 & $0.7 \pm 1.7$ & 53.1 \\
\hline
\end{tabular}

19 operated embryos between stages 21 and 23 that contained regions of spinal cord lacking a floor plate were hybridised with an mRNA probe for CASH-1. In addition, adjacent sections from 9 of these embryos were hybridised with an mRNA probe for SCG10, 5 embryos with a Phox 2 probe and 5 with a GATA-2 probe. The number of cells positive for each marker in serial sections was counted and compared with unoperated controls. This comparison is presented in two

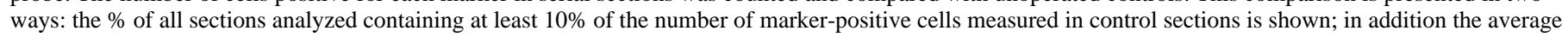
number of marker-positive cells per section $\pm \mathrm{s}$. e. $\mathrm{m}$. is presented. The fold-reduction in the average number of marker-positive cells per section in operated embryos is calculated as the ratio of the average in operated versus control sections.

Regions of spinal cord in which a floor plate was absent tended to be significantly smaller than their unoperated counterparts, and also gave rise to smaller numbers of HNK-1-positive neural crest cells. The reduction in CASH-1 cell number (2.4-fold) correlated reasonably well with the reduction in HNK-1 cells in operated regions. However, the absolute number of SCG10 $0^{+}$cells, and the percentage of sections containing any SCG10 ${ }^{+}$cells was significantly further reduced. GATA-2 and Phox2 expression was virtually extinguished in operated embryos. 

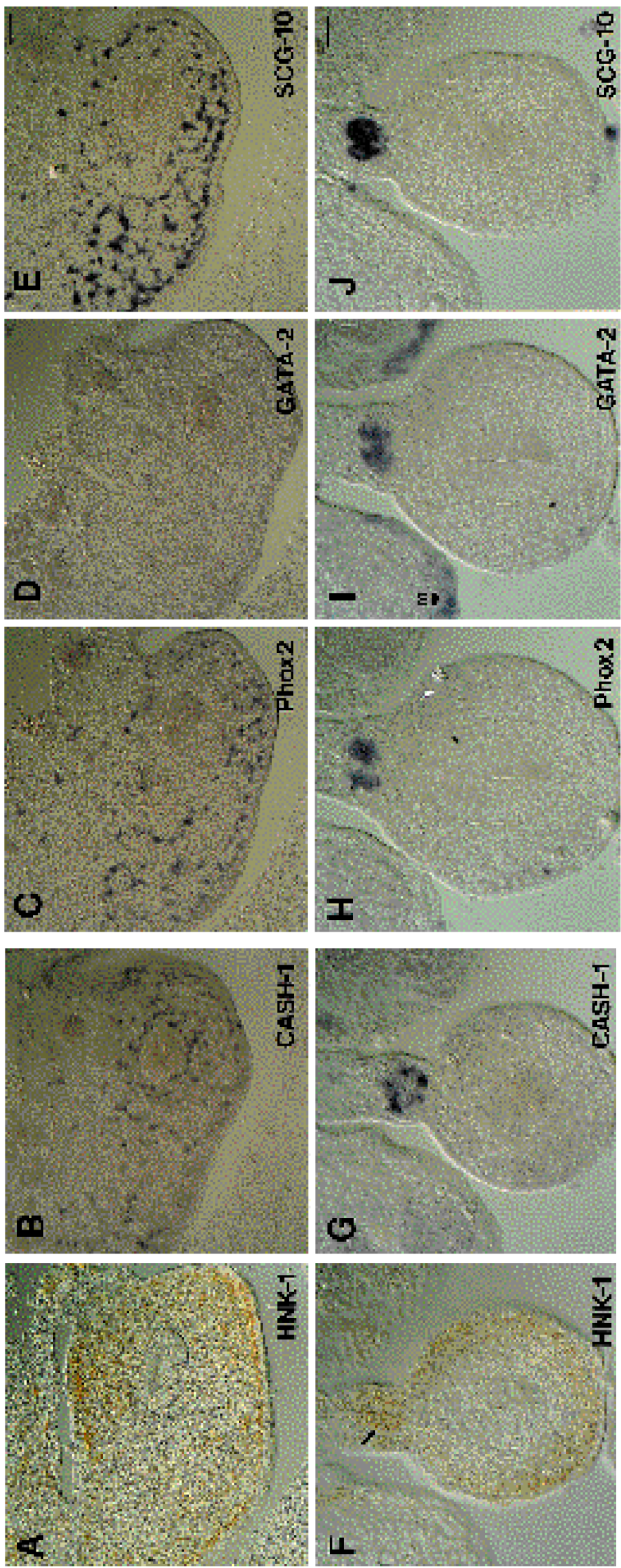

Virtually all sections in regions of operated embryos lacking a floor plate (Fig. 5B,G,L) retained aggregates of HNK-1+ cells near the dorsal aorta (Fig. 5C,H,M). Most if not all sections examined (93.3\%; see Table 2) also contained some Cash $-1^{+}$cells near the dorsal aorta when analyzed at stages $21-$ 23 (Fig. 5D,I,N). However, the number of HNK-1+ and Cash$1^{+}$cells appeared reduced relative to controls: an average of $34 \pm 24.9$ Cash $-1^{+}$cells per section was measured in operated embryos, versus $82.1 \pm 31.3$ Cash $-1^{+}$cells per section at similar axial levels in unoperated embryos, a 2.4-fold reduction (Table 2 ). Although an accurate count of the number of HNK-1positive cells was precluded by the subcellular distribution of the antigen, the reduction in the number of these neural crest cells appeared qualitatively similar to that in the size of the Cash- $1^{+}$population. This suggests that notochord and floor plate ablation reduces the number of aggregating neural crest cells but does not prevent induction of Cash-1 expression within those remaining cells.

A strikingly different result was obtained when expression of GATA-2 and Phox 2 were examined in operated embryos lacking a floor plate. Among 10 such embryos examined at stages $21-23$, most sections lacked GATA- $2^{+}$or Phox $2^{+}$cells (Fig. 5J,O; Table 2), despite the presence of aggregating HNK$1^{+}$and Cash- $1^{+}$neural crest cells in adjacent or near-adjacent sections. Only $3.6 \%$ and $7.7 \%$ of sections in operated embryos contained any GATA-2 or Phox2-positive cells, respectively, whereas $93 \%$ of sections contained Cash- $1^{+}$cells (Table 2 ). In control embryos, by contrast, $100 \%$ of sections contained positive cells for each of the three markers. To quantify this effect more rigorously, the average number of positive cells per section was determined. There was a 36.4-fold and a 53.1fold reduction in the average number of Phox $2^{+}$and GATA$2^{+}$cells per section (mean $=1.3 \pm 2.0$ and $0.7 \pm 1.7$ cells/section), respectively (Table 2 ), whereas as mentioned above there was only a 2.4 -fold reduction in the average number of Cash- $1^{+}$ cells per section. Similar results were obtained in embryos analyzed at stages 25-27 (see below). These results suggest that GATA-2 and Phox 2 expression are dependent upon the ventral neural tube, whereas Cash-1 expression is at least partially independent of it.

The pan-neuronal marker SCG10 behaved differently to the sympathoadrenal markers GATA-2, Phox 2 and TH (see Fig. $7 \mathrm{H}$, below) in embryos lacking a notochord and floor plate. Almost $40 \%$ of the sections examined in operated embryos contained at least some SCG10 $10^{+}$cells (Fig. 5E; Table 2), whereas (as mentioned above) only $3.6 \%$ and $7.7 \%$ of sections contained any GATA $-2^{+}$or Phox $2^{+}$cells, respectively. Moreover, while there was a 5.5-fold reduction in the average

Fig. 3. Expression of CASH-1, Phox2, GATA-2 and SCG10 in the enteric nervous system and Remak's ganglion. Serial $25 \mu \mathrm{m}$ transverse sections through the stomach (A-E) and a region just rostral to the hindlimb containing Remak's ganglion (F-J) of a stage 25 embryo were processed for immunocytochemistry with the HNK1 antibody (A,F) to reveal neural crest cells, and for in situ hybridisation with mRNA probes for CASH-1 (B,G), Phox2 (C,H), GATA-2 (D,I) and SCG10 (E,J). Differentiating neural crest cells in Remak's ganglion (arrow, F) expess all four mRNAs, and those in the stomach express CASH-1, Phox2, SCG10 but not GATA-2 (D). GATA-2 is also expressed in the mesonephros (' $\mathrm{m}$ ' in I).

Magnification bar, $75 \mu \mathrm{m}(\mathrm{E}), 37.5 \mu \mathrm{m}(\mathrm{J})$. 
number of SCG10+ $10^{+}$cells per section, this was substantially smaller than the 35- to 50-fold reduction in the number of Phox $2^{+}$and GATA- $2^{+}$cells. Thus, in a substantial proportion of embryos lacking a floor plate, $\mathrm{SCG} 10^{+}$cells are able to develop (albeit in reduced numbers) near the dorsal aorta, despite the fact that these cells do not express Phox 2 or GATA2 . The number of $\mathrm{SCG}_{10} 0^{+}$cells may be reduced in operated embryos as a direct or indirect consequence of the overall reduction in neural crest cell number near the dorsal aorta. The reason for this reduction in crest cell number is not clear. It may reflect a decreased production, proliferation or survival of such cells, due to the smaller size of the neural tube.

Expression of TH was analyzed in operated embryos lacking a floor plate (Fig. 7D) at stages 25-27. TH immunoreactivity was absent from virtually all sections examined in these embryos (Fig. $7 \mathrm{H}$ ), despite the presence of $\mathrm{HNK}-1^{+}$neural crest cells near the dorsal aorta in adjacent serial sections (Fig. $7 \mathrm{~F})$. As was the case for the younger series of embryos, virtually no Phox 2 or GATA-2 expression was seen in operated regions (not shown). The average number of $\mathrm{SCG} 10^{+}$cells per section was, if anything, higher in these older operated embryos, indicating that the persistence of SCG10 expression in younger embryos cannot be due simply to a longer half-life of this mRNA compared to that of the other genes examined. In sum, these data indicate that ablation of the notochord and floor plate completely blocks expression of $\mathrm{TH}$, whereas it allows expression of SCG10 in many sympathetic cells.

In contrast to its effects on sympathetic neurons, notochord/floor plate ablation had no detectable effect on the expression of Phox2, GATA-2 and SCG10 in other autonomic neuronal populations. In sections lacking a floor plate, Phox 2 expression was detected in the developing gut (Fig. 6E), and both Phox2 and GATA-2 expression were detected in Remak's ganglion (Fig. 6H,K) at stages 25-27, despite the absence of these markers in sympathetic ganglia in the same sections (not shown). SCG10 expression, like that of Phox2 and GATA2,
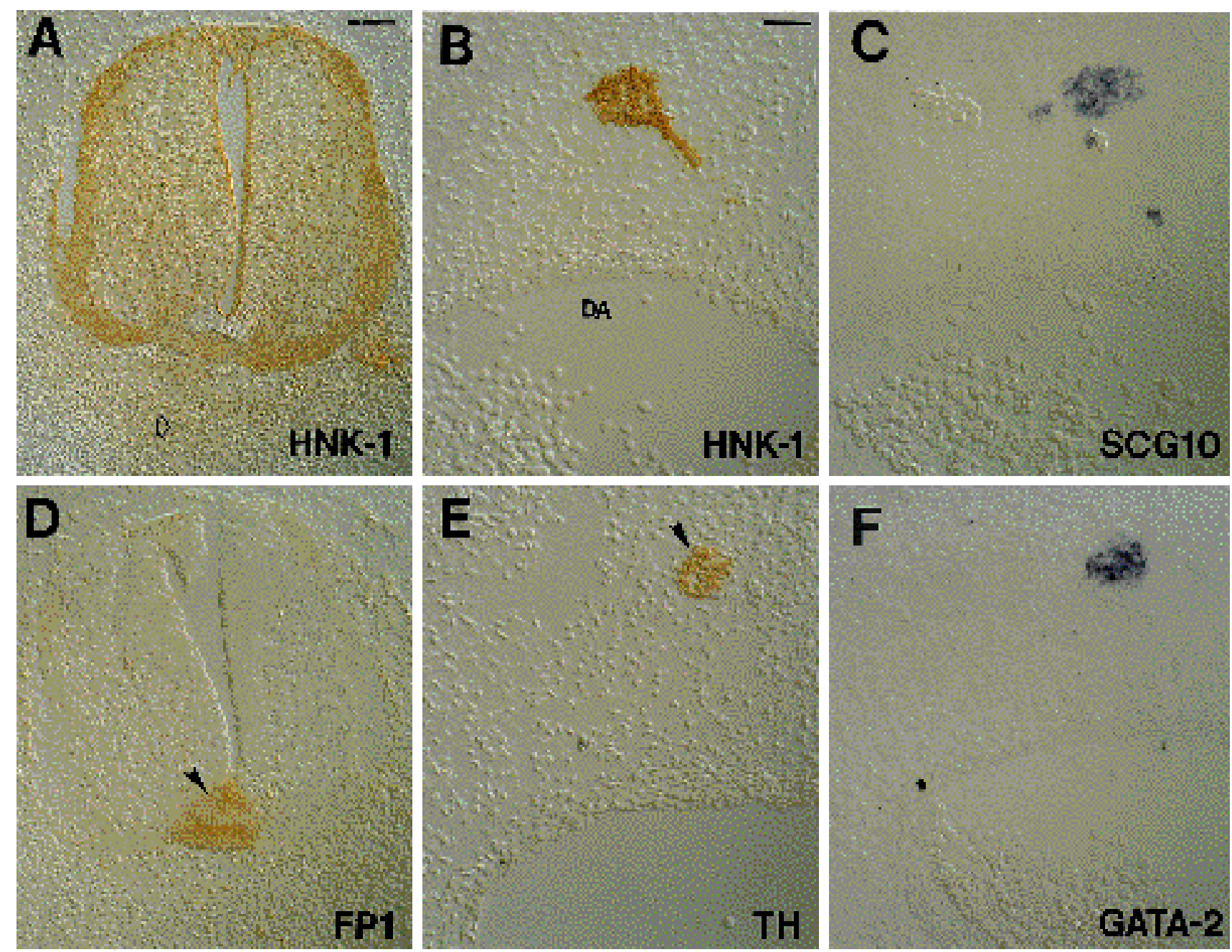

Fig. 4. The notochord is not required for sympathetic neuronal differentiation in the presence of ventral neural tube structures. Serial $15 \mu \mathrm{m}$ transverse sections are shown from an embryo at ca. stage 26 in which the notochord had been removed, but in which a floor plate (arrowhead, D) and other ventral neural tube structures still formed. Sections were processed for immunocytochemistry with the HNK-1 antibody (A,B), FP1 antibody (D), and an antibody to tyrosine hydroxylase (E), and for in situ hybridisation with mRNA probes to SCG10 (C) and GATA-2 (F). A faint HNK-1-positive matrix can be seen ventral to the neural tube where the notochord was removed (open arrowhead, A). Normal expression of CASH-1 and Phox 2 was also seen in similar embryos (not shown). Arrowhead (E) indicates $\mathrm{TH}^{+}$cells in sympathetic ganglion. 'DA' indicates dorsal aorta (B). Scale bars, $75 \mu \mathrm{m}$ (A) and $37.5 \mu \mathrm{m}$ (B). 


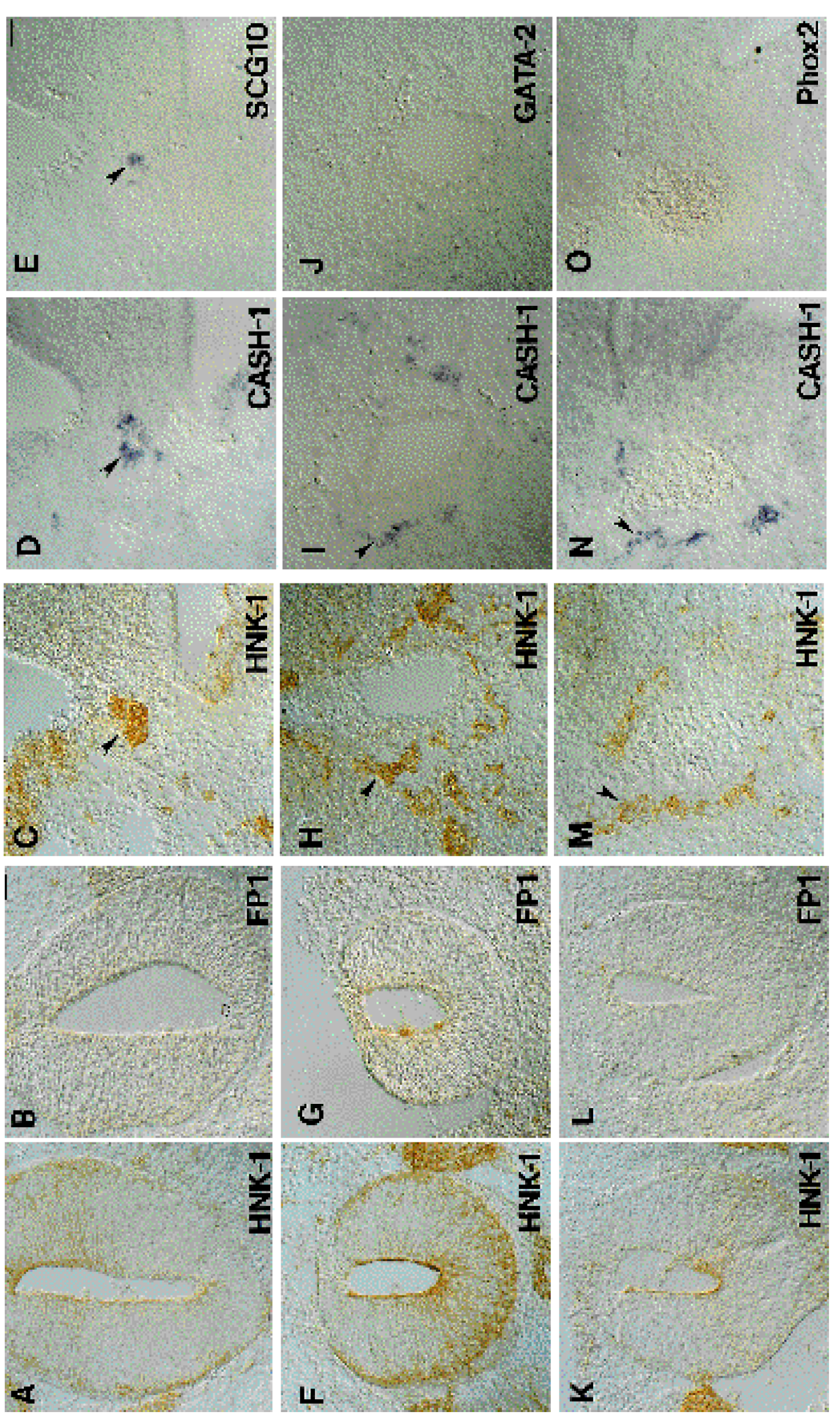

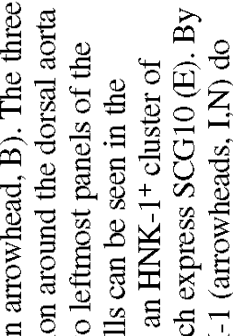

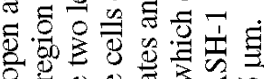

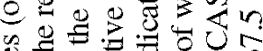

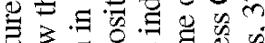

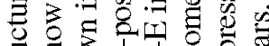

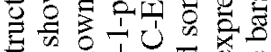
ชิ

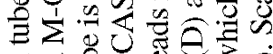

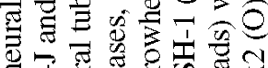

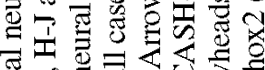

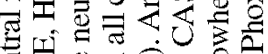

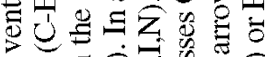
o 8

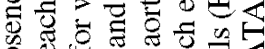

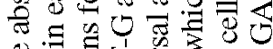

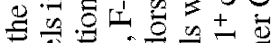
政事

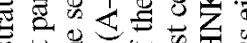
क w

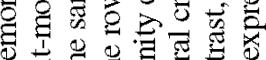

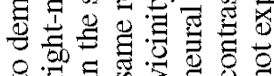

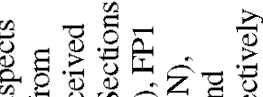

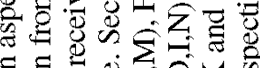

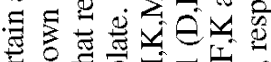

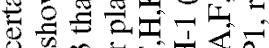

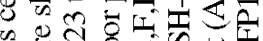

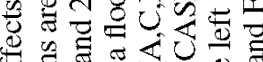
.

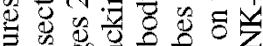

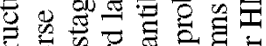

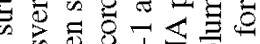

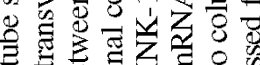

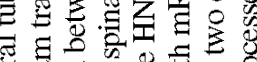

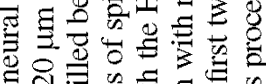

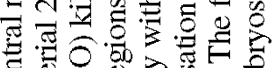

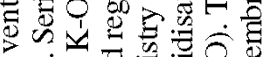
$4 \dot{0}$

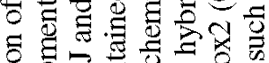

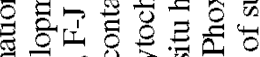
品

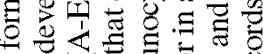
응

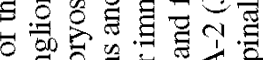

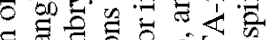

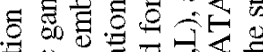

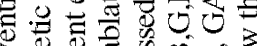

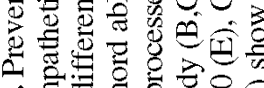
的解 형

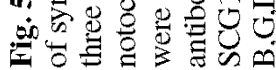



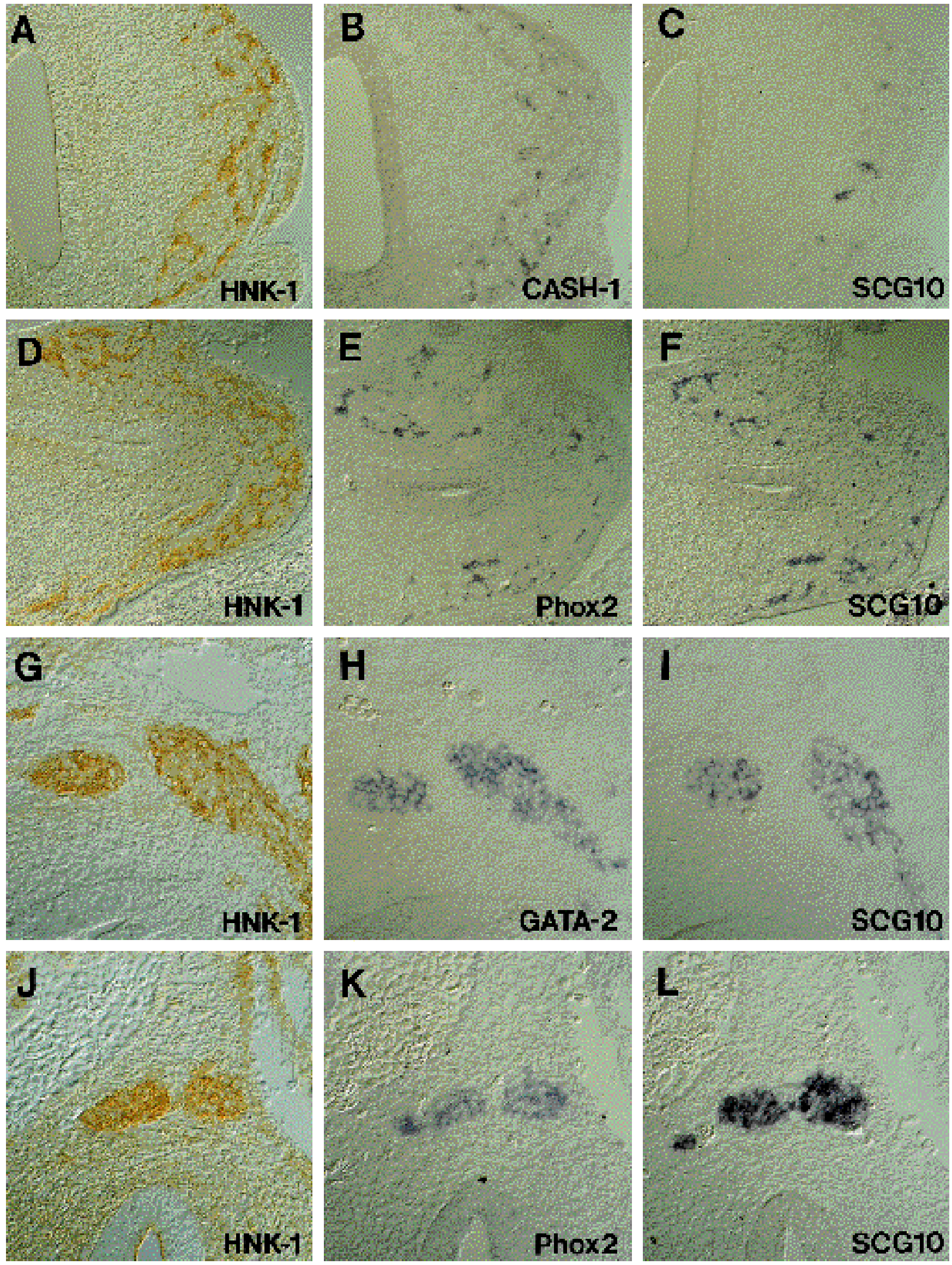

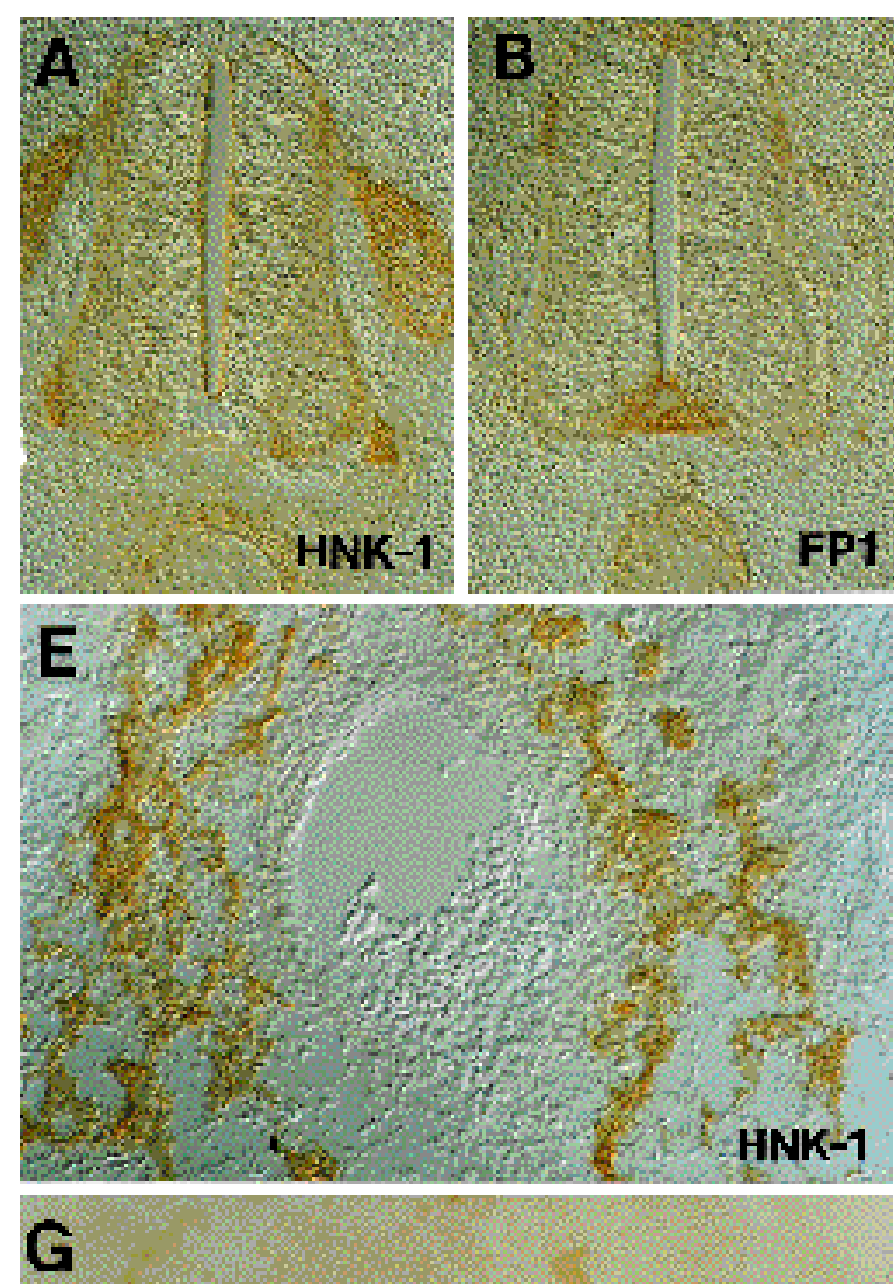

TH
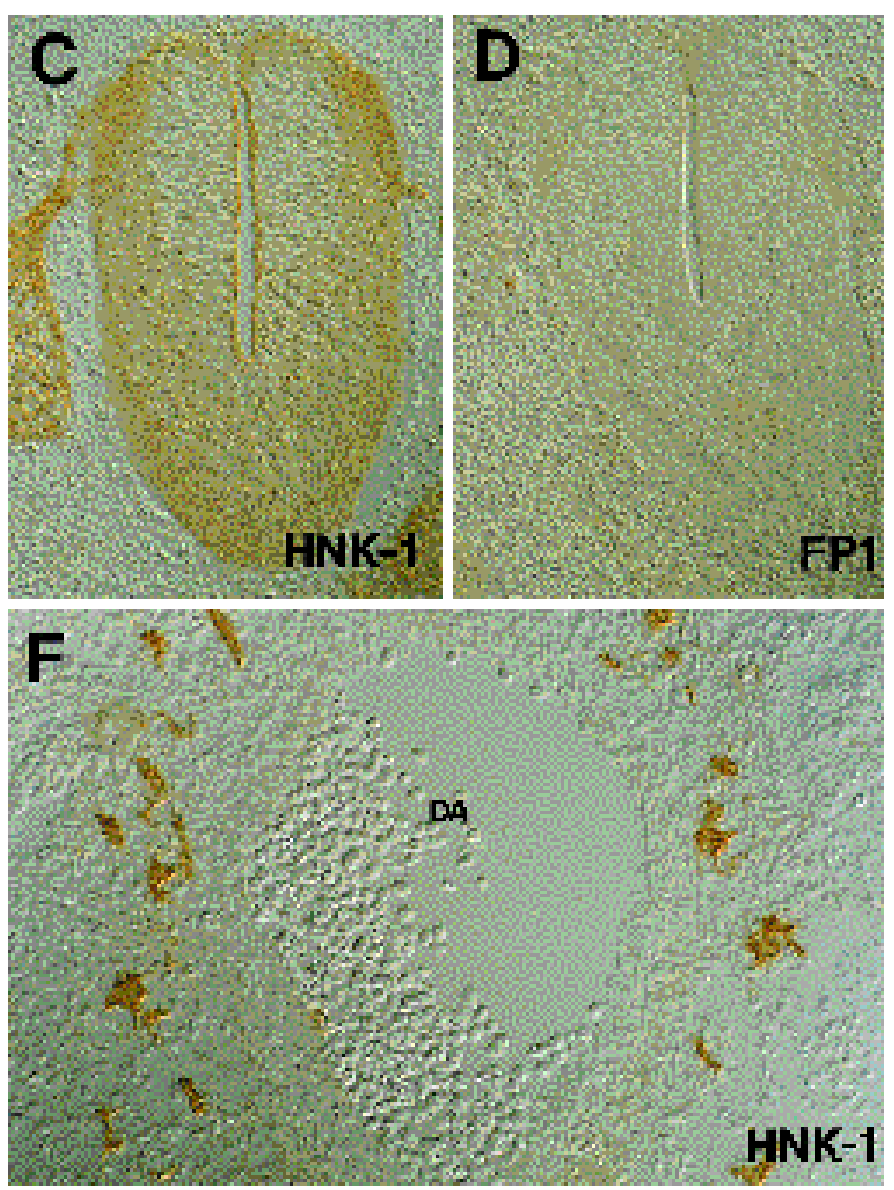

H

ТH
Fig. 6. Perturbation of the notochord and ventral neural tube has no effect on the differentiation of neural crest cells in the gut or in Remak's ganglion. Serial $15 \mu \mathrm{m}$ transverse sections are shown of the stomach (A-F) and Remak's ganglion (G-L) from four embryos (AC, D-F, G-I and J-L) that received notochord ablations and that were analyzed between stages 25 and 27. All sections shown are from regions of the embryos wherein the spinal cord lacked a floor plate as determined by FP1 staining (not shown). Sections were processed for immunocytochemistry with the HNK-1 antibody (A,D,G,J), and for in situ hybridisation with mRNA probes for SCG10 (C,F,I,L), CASH-1 (B), Phox2 (E,K) and GATA-2 (H). CASH- $1^{+}$cells were also detected in Remak's ganglion (not shown).
Fig. 7. Ventral neural tube structures are also required for the expression of tyrosine hydroxylase in developing sympathetic ganglia. Serial $15 \mu \mathrm{m}$ transverse sections are shown from stage 26 unoperated embryos (A,B,E,G), and from a similar axial level of an embryo of similar age in which the notochord was removed and that contained regions of spinal cord lacking a floor plate (D). Sections were processed for immunocytochemistry with the HNK-1 antibody (A,C,E,F), FP1 antibody (B,D), and an antibody to tyrosine hydroxylase $(\mathrm{G}, \mathrm{H})$. The spinal cord region of unoperated and operated embryos is shown in panels A-D. Panels E-H show the region around the dorsal aorta (DA) in the same sections. Note that no TH staining is detected in operated embryos (compare $\mathrm{G}, \mathrm{H}$ ) although $\mathrm{HNK}-1^{+}$cells are present near the dorsal aorta $(\mathrm{F})$. The faintly stained cell cluster within the dorsal aorta in $(\mathrm{H})$ is an artifact. 


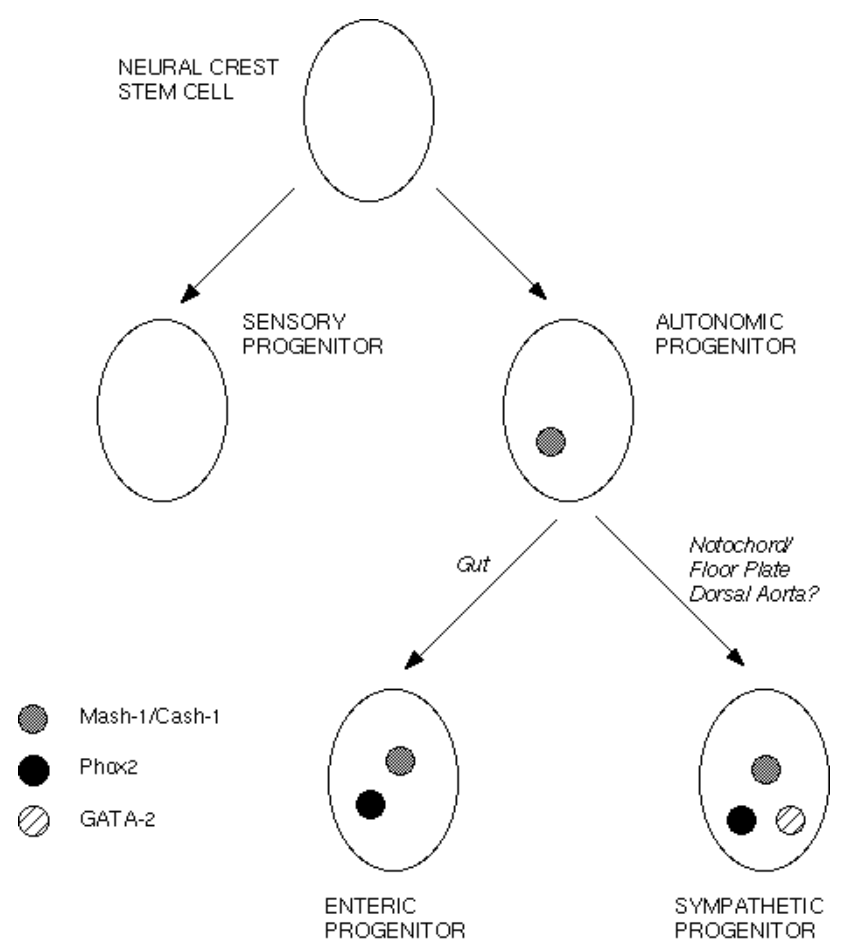

Fig. 8. Schematic diagram illustrating the possible combinatorial control of cellular phenotype by transcription factors during neural crest development. The expression of a sympathetic phenotype involves the action of at least three transcriptional regulators: Mash$1 /$ Cash-1, whose expression is controlled by unknown factors, and GATA-2 and Phox 2 whose expression is dependent upon inductive signals from the notochord and/or floorplate, and possibly the dorsal aorta as well (Stern et al., 1991). The expression of an enteric phenotype also involves the action Mash-1/Cash-1 and of Phox2, but not of GATA-2. Phox2 expression in enteric neurons may be controlled by inductive signals present in the developing gut. Mash1/Cash-1 function may specify pan-neuronal properties of developing neurons, whereas Phox 2 and GATA-2 may be important for the expression of a particular neurotransmitter phenotype.

also appeared unaffected in the gut and Remak's ganglion (Fig. $6 \mathrm{C}, \mathrm{F}, \mathrm{I}$ and L). These results indicate that notochord/floor plate ablation not only affects a subset of the transcription factors expressed in developing autonomic precursors, but does so in a position-specific manner. This suggests that proximity to the ventral neural tube and/or notochord is important for the expression of Phox 2 and GATA-2 in sympathetic precursors, but not in other autonomic precursor populations.

As mentioned earlier, regions of embryos in which the floor plate was absent contained fewer HNK-1-positive cells in both the sensory and sympathetic ganglia. The effect of notochord/floor plate ablation on the markers examined could, therefore, simply be due to a reduction in neural crest cell number near the dorsal aorta. To address this possibility, we examined several embryos lacking a notochord in which the neural tube contained a floor plate, but had been surgically rotated by approximately $90^{\circ}$. Such embryos exhibited essentially normal numbers of HNK-1-positive cells in the vicinity of the dorsal aorta. Despite the fact that these neural tuberotated embryos embryos contained a floor plate, virtually none of the $\mathrm{HNK}-1^{+}$cells near the dorsal aorta expressed $\mathrm{TH}$,
GATA-2 or Phox2 (data not shown). This observation suggests that proximity of sympathetic precursor cells to the ventral neural tube, rather than simply a threshold number of such cells near the dorsal aorta, is necessary for their normal phenotypic differentiation.

\section{DISCUSSION}

We have used the sympathoadrenal lineage of the neural crest to dissect the regulation of lineage-specific transcription factors and terminal differentiation genes during neuronal differentiation. Our data reveal a sequential expression of transcription factor-encoding genes that uncovers a series of previously hidden steps in the development of sympathetic neurons. Neural crest cells identified by expression of HNK-1 migrate to the dorsal aorta, aggregate and first begin to express Cash-1, the chick homolog of Mash-1. One stage later, these cells begin to express two other transcription factors, Phox2 and GATA-2. Shortly thereafter, expression of SCG10 marking the acquisition of a neuronal phenotype - is first detected. This is followed up to a day later by expression of the neurotransmitter enzyme TH. Quantitative analysis of marker expression in adjacent serial sections supports the idea that these genes are sequentially expressed by a single developing cell population and not by multiple intermingled subpopulations. Thus, as in the hematopoietic system (Dexter et al., 1990), the development of sympathetic progenitor cells involves transitions through a series of intermediate states. The biological function of such multiple transitions in the commitment and differentiation processes remains to be determined.

\section{Role of the notochord and floor plate in early sympathetic development}

The notochord and/or floor plate have previously been shown to be required for the acquisition of catecholamine histofluorescence by developing sympathetic neurons (Stern et al., 1991). Our analysis using additional markers reveals that only a part of the genetic program in sympathetic precursors is dependent upon these tissues. Expression of Cash-1, the earliest transcription factor marker of sympathetic precursors, can occur in the absence of ventral neural tube-derived signals. Expression of the pan-neuronal marker SCG10 is also detected, although the number of positive cells is reduced relative to controls. By contrast, the induction of two later transcription factor genes, Phox 2 and GATA-2, like that of the neurotransmitter phenotypic markers TH and catecholamine fluorescence, is dependent upon such signals. Given that the markers used define a single cell population (see above), these results suggest that the sequential appearance of these markers does not reflect a simple linear genetic regulatory pathway, but rather two or more superimposed pathways, only one of which is absolutely dependent upon signals from the notochord/VNT.

Our results do not address whether the notochord/VNT exert a direct or indirect effect on neural crest cells. Nor do they distinguish whether these tissues are sufficient or merely necessary for sympathetic development. In vitro reconstitution experiments have indicated that the notochord and floor plate exert a direct influence on spinal cord development (Placzek et al., 1993; Yamada et al., 1993), and it is tempting to speculate that these structures exert a similar direct influence on nearby 
migrating neural crest cells. However, the notochord has been shown to pattern the somites as well, and therefore it is possible that the effects of the notochord/VNT on sympathetic development are mediated indirectly through their effects on paraxial mesoderm patterning (Brand-Saberi et al., 1993; Goulding et al., 1994; Koseki et al., 1993; Pourquie et al., 1993). In vitro reconstitution experiments could address this issue, as well as the question of whether other structures, such as the dorsal aorta, are also required for sympathetic development as previously suggested (Stern et al., 1991). Such experiments would in addition provide an assay for the specific molecules affecting sympathetic precursor development.

\section{Regulation and function of transcription factor genes in neural crest development}

Mash-1 and Cash-1, vertebrate homologs of the Drosophila achaete-scute genes, are transiently expressed by neural crest cells shortly after they cease migration near the dorsal aorta (Lo et al., 1991). Targeted mutagenesis experiments in mice have shown that, in the absence of Mash-1 function, sympathetic, parasympathetic and a subpopulation of enteric neurons never develop as assessed by expression of SCG10, neurofilament, TH, DBH and other markers (Guillemot et al., 1993). Thus, Mash-1 is necessary for autonomic neurogenesis. The present results indicate, however, that Cash-1 is not sufficient for the expression of all aspects of a sympathetic phenotype, since floor plate ablation has little effect on the expression of Cash-1, yet prevents expression of TH. Taken together, these data suggest that the expression of a sympathetic phenotype requires both the action of Mash-1, and also of notochord/VNT-derived signals which are necessary for catecholamine synthesis in these cells (Fig. 8). The factors controlling expression of Mash-1/Cash-1 remain to be identified.

Unlike Cash-1, the induction of both Phox 2 and GATA-2 appears to depend on VNT-derived signals. This is consistent with our observation that Phox 2 and GATA-2 normally are expressed on a distinct schedule from Cash-1. While Phox2 and GATA-2 are regulated differently from Cash-1, however, their expression may nevertheless depend upon the latter gene. In Mash-1 homozygous null mouse embryos, neither GATA2 nor Phox 2 expression is detected in the vicinity of the dorsal aorta(L. Sommer, L. Lo and D. Anderson, unpublished). This suggests that induction of GATA-2 and Phox 2 may require Mash- 1 function as well as signals from the notochord and floor plate.

Little is known about the function of GATA-2 and Phox 2 in the nervous system. Phox 2 expression correlates well with the expression of catecholamine biosynthetic enzymes such as DBH (Valarché et al., 1993). Indeed, Phox2 binding sites have been detected in the DBH promoter (Tissier-Seta et al., 1993). The idea that Phox 2 is necessary for expression of catecholamine neurotransmitter enzymes in sympathetic precursors is consistent with our observation that notochord/floor plate ablation blocks both Phox 2 induction and that of TH. The same holds true for GATA-2, suggesting that this gene could also be involved in catecholaminergic expression. However, during erythropoeisis, forced expression of GATA-2 leads to a block in differentiation of progenitor cells (Briegel et al., 1993), presumably by interfering with the normal down-regulation of endogenous GATA-2 that occurs during this period. GATA-2 could thus play an analagous role to inhibit or delay differentiation in the sympathetic lineage as well. In this respect, it is noteworthy that GATA-2 is homologous to the Drosophila gene pannier, a negative regulator of achaete-scute (Ramain et al., 1993). This homology, and the temporal sequence of Cash-1 and GATA-2 expression, suggests that the latter gene may be required to extinguish expression of the former.

\section{Parallel regulation of different components of the differentiated sympathetic phenotype}

Notochord/floor plate removal prevents the expression of two markers of the neurotransmitter phenotype in developing sympathetic ganglia: catecholamine histofluorescence (Stern et al., 1991) and TH (this study). Surprisingly, however this manipulation allowed continued expression in many sympathetic cells of a pan-neuronal marker, SCG10. This suggests that the induction of pan-neuronal and neurotransmitter enzyme genes are under independent control in sympathetic neuron precursors. Several other independent lines of evidence support this idea. First, during normal development in vivo, SCG10 and TH appear sequentially and not coordinately (this study). Second, in rat or mouse neural crest cultures $\mathrm{SCG}_{10}{ }^{+}$neurons develop but do not express TH or DBH unless co-cultured with inducing tissues (A. Groves, M. Rao and D. Anderson, unpublished data). Third, in cultures of avian trunk neural crest, the catecholaminergic cells that develop do not express neuronal markers and do not exhibit a neuronal morphology (Christie et al., 1987; Fauquet et al., 1981; LeBlanc et al., 1990); conversely most neuronal cells in similar cultures do not express TH (Sextier-Sainte-Claire Deville et al., 1994).

Taken together, these data support the concept that the neuronal and neurotransmitter components of the sympathetic phenotype are under independent genetic and epigenetic control (Fig. 8). It is well established that the neurotransmitter phenotype of mature sympathetic neurons can be altered by target-derived instructive factors, independent of the neuronal aspect of the phenotype (for reviews, see Patterson, 1990; Patterson and Nawa, 1993). The present data indicate that this independent regulation is exerted at the initial stages of sympathetic neuron differentiation as well. However, in this case, the sources of the neurotransmitter-enzyme inducing signals are not targets of sympathetic innervation, but rather stuctures past which neural crest cells migrate.

\section{Cascades of transcriptional regulators in neuronal development}

The results presented in this paper suggest a simple logic for action of transcriptional regulatory genes that control the diversification of autonomic neurons (Fig. 8). Shortly after emigration from the dorsal neural tube, some neural crest cells may become restricted to an autonomic fate (LeDouarin, 1986). The expression of Mash-1/Cash-1 in these progenitor cells may endow them with the capacity to generate multiple classes of autonomic neurons throughout the embryo (Anderson, 1993b). Upon exposure to different microenvironments, these autonomic progenitors may then be induced to express other transcription factors, such as Phox 2 and GATA-2, which determine the particular autonomic neurotransmitter phenotype characteristic of sympathetic, parasympathetic or enteric neurons.

Such a working hypothesis, while undoubtedly over-simpli- 
fied, illustrates the way in which transcriptional regulators may control different aspects of neural crest development. It also emphasizes two important points implicit in genetic studies of neurogenesis (Dambly-Chaudiere et al., 1988; Desai et al., 1988). The first is that cascades of sequentially expressed transcription factors in developing neurogenic lineages may reflect parallel as well as serial functions for these factors. The second is that such transcription factors may be under independent control by signals acting from outside the cell. If, as suggested by our data, different transcriptional regulators are functionally assigned to different components of the differentiated neuronal phenotype, it would provide a rationale for their independent regulation and parallel function. It should be possible, through the use of in vitro systems and genetic perturbations, to identify both the specific signals that control the expression of these transcription factors and the precise functions that they exert within developing neuronal precursor cells.

We are grateful to Dr Tom Reh for providing chick Cash-1 cDNA clones in advance of publication, and to Dr Christo Goridis for communicating results on Phox 2 in advance of publication and for his useful comments on the manuscript. We wish to thank Dr Tom Jessell and Dr Hiroshi Hatanaka for gifts of the FP1 and PCTH-7 antibodies respectively, and to Dr Peter Jeffrey for his gift of the chicken SCG10 cDNA. A. K. G. is grateful to Cheryll Tickle for introducing him to chick embryology, and to Claudio Stern for demonstrating notochord removal. We would like to thank Kai Zinn for the use of his microscopy facilities, Steve Padilla for technical assistance and Liching Lo for advice on the in situ hybridization procedure. This work was supported by a Long Term Fellowship from the Human Frontiers Science Program Organization (A. K. G.), NIH grant GM 28896 (J. D. E.), NIH training grant GM 08061 (K. M. G.), NIH grant NS23476 (D. J. A.) and by grants from the Association pour la Recherche Contre le Cancer and the Association Française contre les Myopathies (J.-F. B.). D. J. A. is an Associate Investigator of the Howard Hughes Medical Institute.

\section{REFERENCES}

Anderson, D. J. (1993a). Cell fate determination in the peripheral nervous system: The sympathoadrenal progenitor. J. Neurobiol. 24, 185-198.

Anderson, D. J. (1993b). MASH genes and the logic of neural crest cell lineage diversification. C.R. Acad. Sci. Paris (Life Sciences) 316, 1090-1096.

Anderson, D. J. (1993c). Molecular control of cell fate in the neural crest: the sympathoadrenal lineage. Anпи. Rev. Neurosci. 16, 129-158.

Anderson, D. J. and Axel, R. (1985). Molecular probes for the development and plasticity of neural crest derivatives. Cell 42, 649-662.

Artinger, K. B. and Bronner-Fraser, M. (1993). Delayed formation of the floor plate after ablation of the avian notochord. Neuron 11, 1147-1161.

Baetge, G. and Gershon, M. D. (1989). Transient catecholaminergic (TC) cells in the vagus nerves and bowel of fetal mice: relationship to the development of enteric neurons. Dev. Biol 132, 189-211.

Baetge, G., Pintar, J. E. and Gershon, M. D. (1990). Transiently catecholaminergic (TC) cells in the bowel of the fetal rat: precursors of noncatecholaminergic enteric neurons. Dev. Biol. 141, 353-380.

Birren, S. J., Lo, L. C. and Anderson, D. J. (1993). Sympathetic neurons undergo a developmental switch in trophic dependence. Development 119, 597-610.

Brand-Saberi, B., Ebensperger, C., Wilting, J., Balling, R. and Christ, B. (1993). The ventralizing effect of the notochord on somite differentiation in chick embryos. Anatomy and Embryology 188, 239-245.

Briegel, K., Lim, K.-C., Plank, C., Beug, H., Engel, J. D. and Zenke, M. (1993). Ectopic expression of a conditional GATA-2/estrogen receptor chimera arrests erythroid differentiation in a hormone-dependent manner. Genes Dev. 7, 1097-1109.

Bronner-Fraser, M. and Fraser, S. (1988). Cell lineage analysis shows multipotentiality of some avian neural crest cells. Nature 335, 161-164.

Cantino, D., Barasa, A. and Gugliemone, R. (1982). Catecholamine- containing neurons in Remak's Ganglion: a developmental and tissue culture study. J. Neurocytol. 11, 763-778.

Carnahan, J. F., Anderson, D. J. and Patterson, P. H. (1991). Evidence that enteric neurons may derive from the sympathoadrenal lineage. Dev. Biol. 148, 552-561.

Christie, D. S., Forbes, M. E. and Maxwell, G. D. (1987). Phenotypic properties of catecholamine-positive cells that differentiate in avian neural crest cultures. J. Neurosci. 7, 3749-3763.

Cochard, P., Goldstein, M. and Black, I. (1979). Initial development of the noradrenergic phenotype in autonomic neuroblasts of the rat embryo in vivo. Dev. Biol. 71, 1900-114.

Cochard, P. and Paulin, D. (1984). Initial expression of neurofilaments and vimentin in the central and peripheral nervous system of the mouse embryo in vivo. J. Neurosci. 4, 2080-2094.

Cohen, A. M. (1972). Factors directing the expression of sympathetic nerve traits in cells of neural crest origin. J. Exp. Zool.179, 167-182.

Dambly-Chaudiere, C., Ghysen, A., Jan, L. Y. and Jan, Y. N. (1988). The determination of sense organs in Drosophila: interaction of scute and daughterless. Roux's Arch Dev Biol 197, 419-423.

Desai, C., Garriga, G., McIntire, S. L. and Horvitz, H. R. (1988). A genetic pathway for the development of the Caenorhabditis elegans HSN motor neurons. Nature 336, 638-646.

Dexter, T. M., Heyworth, C. M., Spooncer, E. and Ponting, I. L. O. (1990). The role of growth factors in self-renewal and differentiation of haemopoietic stem cells. Phil. Trans. R. Soc. Lond. B 327, 85-98.

Fauquet, M., Smith, J., Ziller, C. and LeDouarin, N. M. (1981). Differentiation of autonomic neuron precursors in vitro: cholinergic and adrenergic traits in cultured neural crest cells. J. Neurosci. 1, 478-492.

Ghysen, A. and Dambly-Chaudiere, C. (1989). Genesis of the Drosophila peripheral nervous system. Trends Genet. 5, 251-255.

Ghysen, A. and Dambly-Chaudiere, C. (1992). Development of the peripheral nervous system in Drosophila. In Determinants of Neuronal Identity, (ed. M. Shankland and E. R. Macagno). pp. 226-292. San Diego: Academic Press, Inc.

Ghysen, A., Dambly-Chaudiere, C., Jan, L. Y. and Jan, Y.-N. (1993). Cell interactions and gene interactions in peripheral neurogenesis. Genes Dev. 7, 723-733.

Goulding, M., Lumsden, A. and Gruss, P. (1993). Signals from the notochord and floor plate regulate the region-specific expression of two Pax genes in the developing spinal cord. Development 117, 1001-1016.

Goulding, M., Lumsden, A. and Paquette, A. J. (1994). Regulation of Pax-3 expression in the dermamyotome and its role in muscle development. Development 120, 957-971.

Guillemot, F., Lo, L.-C., Johnson, J. E., Auerbach, A., Anderson, D. J. and Joyner, A. L. (1993). Mammalian achaete-scute homolog-1 is required for the early development of olfactory and autonomic neurons. Cell 75, 463-476.

Hamburger, V. and Hamilton, H. L. (1992). A series of normal stages in the development of the chick embryo. Developmental Dynamics 195, 231-272.

Harland, R. M. (1991). In situ hybridization: an improved whole mount method for Xenopus embryos. In Methods in Cell Biology (ed. B. K. Kay and H. J. Peng). Vol. 36. pp. 675-685. New York: Academic Press.

Hirano, S., Fuse, S. and Sohal, G. S. (1991). The effect of the floor plate on pattern and polarity in the developing central nervous system. Science 251, 310-313.

Howard, M., and Bronner-Fraser, M. (1986). Neural tube derived factors influence the differentiation of neural crest cellsin vitro: Effects on activity of neurotransmitter biosynthetic enzymes. Dev. Biol. 117, 45-54.

Jasoni, C. L., Walker, M. B., Morris, M. D. and Reh, T. A. (1994). A chicken achaete-scute homolog (CASH-1) is expressed in a temporally and spatially discrete manner in the developing central nervous system. Development 120, 769-783.

Johnson, J. E., Birren, S. J. and Anderson, D. J. (1990). Two rat homologues of Drosophila achaete-scute specifically expressed in neuronal precursors. Nature 346, 858-861.

Kalcheim, C. and Le Douarin, N. M. (1986). Requirement of a neural tube signal for the differentiation of neural crest cells into dorsal root ganglia. Dev. Biol. 116, 451-466.

Koseki, H., Wallin, J., Wilting, J., Mizutani, Y., Kispert, A., Ebensperger, C., Herrmann, B. G., Christ, B. and Balling, R. (1993). A role for Pax-1 as a mediator of notochordal signals during the dorsoventral specification of vertebrae. Development 119, 649-660.

Landis, S. C. (1992). Cellular and molecular mechanisms determining neurotransmitter phenotypes in sympathetic neurons. In Determinants of 
Neuronal Identity (ed. M. Shankland and E. R. Macagno). pp. 497-523. San Diego: Academic Press, Inc.

LeBlanc, G. G., Epstein, M. L. and Bronner-Fraser, M. E. (1990). Differential development of cholinergic neurons from cranial and trunk neural crest cells in vitro. Dev. Biol. 137, 318-330.

Le Douarin, N. M., Teillet, M. A., Ziller, C. and Smith, J. (1978). Adrenergic differentiation of the cholinergic ciliary and Remak ganglion in avian embryos after in vivo transplantation. Proc. Natn. Acad. Sci., USA 75, 20302034.

LeDouarin, N. M. (1982). The Neural Crest. Cambridge University Press, Cambridge, UK.

LeDouarin, N. M. (1986). Cell line segregation during peripheral nervous system ontogeny. Science 231, 1515-1522.

Lo, L., Guillemot, F., Joyner, A. L. and Anderson, D. J. (1994). MASH-1: A marker and a mutation for mammalian neural crest development. Persp. Dev. Neuro. 2, 191-201.

Lo, L., Johnson, J. E., Wuenschell, C. W., Saito, T. and Anderson, D. J. (1991). Mammalian achaete-scute homolog 1 is transiently expressed by spatially-restricted subsets of early neuroepithelial and neural crest cells. Genes Dev. 5, 1524-1537.

Mercer, E. H., Hoyle, G. W., Kapur, R. P., Brinster, R. L. and Palmiter, R. D. (1991). The dopamine ß-hydroxylase gene promoter directs expression of E. coli lacZ to sympathetic and other neurons in transgenic mice. Neuron 7, 703-716.

Newgreen, D. F. and Erickson, C. A. (1986). The migration of neural crest cells. Int. Rev. Cytol. 103, 89-145.

Norr, S. C. (1973). In vitro analysis of sympathetic neuron differentiaition from chick neural crest cells. Dev. Biol. 34, 16-38.

Patterson, P. H.(1990). Control of cell fate in a vertebrate neurogenic lineage. Cell 62, 1035-1038.

Patterson, P. H. and Nawa, H. (1993). Neuronal differentiation factors/cytokines and synaptic plasticity. Cell/Neuron 72/10, 123-137.

Placzek, M., Jessell, T. M. and Dodd, J. (1993). Induction of floor plate differentiation by contact-dependent, homeogenetic signals. Development 117, 205-218.

Pourquie, O., Coltey, M., Teillet, M. A., Ordahl, C. and Le Douarin, N. M. (1993). Control of dorsoventral patterning of somitic derivatives by notochord and floor plate. Proc. Natn. Acad. Sci., USA 90, 5242-5246.

Ramain, P., Heitzler, P., Haenlin, M. and Simpson, P. (1993). pannier, a negative regulator of achaete and scute in Drosophila, encodes a zinc finger protein with homology to the vertebrate transcription factor GATA-1. Development 119, 1277-1291.

Sextier-Sainte-Claire Deville, F., Ziller, C. and Le Douarin, N. M. (1994). Developmental potentials of enteric neural crest-derived cells in clonal and mass cultures. Dev. Biol. 163, 141-151.

Sieber-Blum, M. and Cohen, A. (1980). Clonal analysis of quail neural crest cells: they are pluripotent and differentiate in vitro in the absence of nonneural crest cells. Dev. Biol. 80, 96-106.

Smith, J. L. and Schoenwolf, G. C. (1989). Notochordal induction of cell wedging in the chick neural plate and its role in neural tube formation. J. Exp. Zool. 250, 49-62.

Stein, R., Mori, N., Matthews, K., Lo, L.-C. and Anderson, D. J. (1988a). The NGF-inducible SCG10 mRNA encodes a novel membrane-bound protein present in growth cones and abundant in developing neurons. Neuron 1, 463-476.

Stein, R., Orit, S. and Anderson, D. J. (1988b). The induction of a neuralspecific gene, SCG10, by nerve growth factor in PC12 cells is transcriptional, protein synthesis dependent, and glucocorticoid inhibitable. Dev. Biol. 127, 316-325

Stern, C. D. (1993). Transplantation in avian embryos. In Essential Developmental Biology: A Practical Approach, (ed. C. D. Stern and P. W. H. Holland). Oxford: IRL Press.

Stern, C. D., Artinger, K. B. and Bronner-Fraser, M. (1991). Tissue interactions affecting the migration and differentiation of neural crest cells in the chick embryo. Development 113, 207-216.

Stern, C. D. and Keynes, R. J. (1987). Interactions between somite cells: the formation and maintenance of segment boundaries in the chick embryo. Development 99, 261-272.

Sternberg, P. W., Liu, K. and Chamberlin, H. M. (1992). Specification of neuronal identity in Caenorhabditis elegans. In Determinants of Neuronal Identity (ed. M. Shankland and E. R. Macagno). pp. 1-43. San Diego: Academic Press, Inc.

Teillet, M. A. (1978). Evolution of the lumbo-sacral neural crest in the avian embryo: origin and differentiation of the ganglionated nerve of Remak studied in interspecific quail-chick. Wilhelm Roux's Arch. Dev. Biol. 184, 251-268.

Teillet, M. A., Cochard, P. and Le Douarin, N. M. (1978). Relative roles of the mesenchymal tissues and of the complex neural tube-notochord on the expression of adrenergic metabolism in neural crest cells. Zoon 6, 115-122.

Teillet, M. A. and Le Douarin, N. M. (1983). Consequences of neural tube and notochord excision on the development of the peripheral nervous system in the chick embryo. Dev. Biol. 98, 192-211.

Tissier-Seta, J.-P., Hirsch, M.-R., Valarché, I., Brunet, J.-F. and Goridis, C. (1993). A possible link between cell adhesion receptors, homeodomain proteins and neuronal identity. C.R. Acad. Sci. Paris316, 1306-1315.

Tucker, G. C., Aoyama, H., Lipinski, M., Tursz T. and Thiery, J.-P. (1984). Identical reactivity of monoclonal antibodies HNK-1 and NC-1: conservation in vertebrates on cells derived from neural primordium and on some leukocytes. Cell Differentiation 14, 223-230.

Valarché, I., Tissier-Seat, J.-P., Hirsch, M.-R., Martinez, S., Goridis, C. and Brunet, J.-F. (1993). The mouse homeodomain protein Phox2 regulates NCAM promoter activity in concert with Cux/CDP and is a putative determinant of neurotransmitter phenotype. Development 119, 881-896.

van Straaten, H. W. M. and Hekking, J. W. M. (1991). Development of floor plate, neurons and axonal outgrowth pattern in the early spinal cord of the notochord-deficient chick embryo. Anatomy and Embryology 184, 55-63.

Weintraub, H., Davis, R., Tapscott, S., Thayer, M., Krause, M., Benezra, R., Blackwell, T. K., Turner, D., Rupp, R., Hollenberg, S., Zhuang, Y. and Lassar, A. (1991). The myoD gene family: nodal point during specification of the muscle cell lineage. Science 251, 761-766.

Wilkinson, D. G. (1992). Whole-mount in situ hybridization of vertebrate embryos. In In Situ Hybridization: A Practical Approach (ed. D. G. Wilkinson). Oxford: IRL Press.

Yamada, T., Pfaff, S., Edlund, T. and Jessell, T. (1993). Control of cell pattern in neural tube: motor neuron induction by diffusible factors from notochord and floor plate. Cell 73, 673-686.

Yamada, T., Placzek, M., Tanaka, H., Dodd, J. and Jessell, T. M. (1991). Control of cell pattern in the developing nervous system: polarizing activity of the floor plate and notochord. Cell 64, 635-647.

Yamamoto, M., Ko., L. J., Leonard, M. W., Beug, H., Orkin, S. H. and Engel, J. D. (1990). Activity and tissue-specific expression of the transcription factor NF-E1 multigene family. Genes Dev. 4, 1650-1662.

(Accepted 10 November 1994) 